\title{
First Assembly at Des Moines
}

\author{
By A. S. BaIleY ${ }^{1}$
}

The Seventh General Assembly, the first to meet at the then new capital of Des Moines, which convened January 11, 1858, was undoubtedly the ablest and most important one in the history of the state." In his "History of Iowa," written in 1902, B. F. Gue says that in many respects it was the most important legislative body that ever convened in Iowa. It developed a group of men who are still regarded as the bright particular stars in our galaxy of distinguished Iowans. ${ }^{3}$

I know we are apt to think that all the great men lived in some former time and that there are no truly great men and leaders today. This may be true in a measure. In all history extraordinary periods have called forth extraordinary men. Every age brings its own heroes, be they great or small, and every generation produces the men best fitted for that generation. It is of the remarkable men and events of that first legislature in Des Moines that I am to speak, largely from personal recollection. But first, I must give a little previous personal history as a proper background.

It so happened that I was a subordinate clerk in the senate of that general assembly of 1858 . I came to Iowa, a boy of 11 years, in mid October; 1846, and in December following the state was admitted into the union. Thus, I had an even start with the state, and have kept pace with it in years, but not in wealth and intellectual progress. With my folks, I landed from

${ }^{1}$ After residing in southeastern Iowa counties many years, particularly in Washington, Iowa, as publisher of the Washington Press, A. C. Bailey lived at Lancaster, Schuyler county, Missouri, where he served as mayor for several years. This article was written by him March 16, 1917, and filed in the Manuscript division of the Iowa State Historical Department, at Des Moines.

2 Oran Faville, lieutenant governor, was president of the senate and Stephen B. Shelledy, speaker of the house.

${ }^{8}$ AnNals of Iowa, Vol. XXX, pp. 316-317. 
a steamboat at Keokuk and in wagons moved up into Henry county. As we passed up the ridge west of Nauvoo, I saw the white tents of a great body of Mormons on the Iowa side, ready to move westward. The main body had already gone on its exodus through the wilderness to the promised land at Salt Lake, leaving a trail of suffering and death through Iowa. At Pisgah, over $400 \mathrm{men}$, women, and children were buried in one Mormon cemetery.

I learned the printing trade in Mount Pleasant, beginning in 1851, and stuck to it for 64 years. In 1858, A. R. Wickersham founded the Washington Press and Thadeus H. Stanton and I were his assistants. Next year, Stanton and I bought the paper and contributed not a little to the election of Charley Foster as senator. I grew ambitious and asked him to assist me in getting a position in the legislature, which he readily consented to do. And that is how I came to be a senate clerk in that legislature of long ago. Senator Foster entered the army in 1862, attained the rank of major, and was killed or died in Tennessee. Mr. Stanton, my partner, also joined the army as' captain of a company, but before getting far into Missouri, was appointed paymaster, and he remained a paymaster all his long life. The last five years of his life, he was Paymaster General of U.S.A. with the rank of brigadier general, and after his retirement, died in Omaha, January 23, 1900. For several years, I have been endeavoring to secure for him his rightful recognition as one of the brave and distinguished sons of Iowa.

\section{Stage Coach Rme to Des Mornes}

I rode all the way from Washington to Des Moines in an old-fashioned stagecoach, a vehicle now obsolete, seen only in pictures. ${ }^{4}$ It carried six passengers, three on a seat, facing each. other, knees interlocked. The

- A pioneer stagecoach is on exhibit in the Museum at the State Historical building in Des Moines. 
"boot" behind carried their baggage. A seventh passenger could ride with the driver, and the place was eagerly sought, because it afforded a better view of the country. At Pella, we stopped at noon to change horses and I strolled up the street, amused and wondering at the wooden shoes and strange garb of the Hollanders, a colony of whom had settled there. They were good and industrious people, just the kind Iowa needed then.

Ioway, as Emerson spoke it, was then as new as a picture just from the hand of the artist. The freshness and flavor of morning pervaded the landscape, and the solitude of untold ages still lingered; the beauty and grandeur of the wild prairies undisturbed. The footprints of the Indians and the buffaloes were still fresh in the soil, while thousands of prairie chickens nested in the tall grass and crooned their mating song to the rising sun. The pioneer who heard the $b-0-0-m$ of the prairie chickens in the early morning could never forget it. Millions of years had passed in which the sun and rain and all the chemistry of nature had been working to fit up this land for the pioneers that should come from New England's rocky coasts and from over the sea; and Iowa, beautiful Iowa, lay waiting in the embrace of the two great rivers of the continent, like a maiden in the arms of her lover - the fairest spot in all the West.

At the time of which I write, the Indians had about all gone from the state. Among the last chiefs to leave northwest Iowa were Inkpaduta, Hole-in-the Day and Si-Don-i-Na-Do-Tah (Two Fingers). The last named was a chief of 500 Sioux warriors and with these braves, he whipped the Pottawattamies, in what are now Webster and Calhoun counties. I am surprised that no town has been named for him in northwest Iowa. He was murdered by a revengeful white man.

I found the new capital filled up with assembly members and visitors. They had traveled as I had done, by stage coach or by private conveyance. The 
first railroad, the Rock Island, reached Davenport, February 22, 1854, and was completed to Iowa City January 1, 1856. Des Moines was then far in the backwoods. The city was crude and backwoodsy too, but everybody was pleased with the location and gratified that the capital was at last sure. Five times the capital of the state had been located. First, by Lieut. Albert Lea, who in 1835 had traversed the great unorganized region known as the Michigan Territory, embracing Wisconsin, Iowa, and Minnesota. Iowa was only a district in that region and Lieutenant Lea found a location for its future capital in a town he called Iowa, on the banks of the Mississippi, ten miles above Muscatine. $\mathrm{He}$ it was who gave name to the state.

\section{Graft in New Capital Site}

When Iowa territory began to take shape, the capital was at Burlington and then at Iowa City. Later the legislature appointed commissioners to locate the capital as near the center of the state as practicable. They fixed on a wild prairie in Jasper county, where they surveyed a large tract of land into lots and named it Monroe City. They bought all the lots of nearby land, and thought they had feathered their nests. The graft was so obvious that the Fifth General Assembly repudiated Monroe City, and ordered commissioners to re-locate the capital within two miles of the Racoon Fork at the Des Moines river. That stuck. There was some scrapping between the west side and the east side in Des Moines, and an incipient scandal developed, but this was speedily smothered, and now we are all proud of our capital city. To conciliate Iowa City, the state university was located there and the old stone capitol became the nucleus for the building structures comprising the great school of today. Thus was the balance kept even, and it may well be debated whether Iowa City did not put one over on Des Moines when it swapped the capital for the university.

At that date Des Moines did not dream of the beau- 
tiful city it is now. There were no street cars, no paving, and only wooden sidewalks. Two broad board walks extended from the Court avenue bridge to the capitol on the hill. Half way up on the north side stood the rather handsome cottage of Stuart Goodrell, and lucky were the members who found lodging there. The little home where I found lodging was soon swept away by improvements and I cannot now pick out the spot where it stood.

Governor Grimes and other prominent members boarded at the Des Moines House, then the swell hotel of the city, although it would not pass for a third-class house in any town in Iowa now. The governor always rose early and came down stairs in his shirt sleeves. A guest from Massachusetts mistook him for the porter and ordered him to bring down his trunk, which the governor did, and when the stranger learned who the "porter" was, he was profuse in his apologies.

Samuel E. Rankin, representative from Washington county, Senator Reiner of Louisa county and I found a boarding place in a small residence at the foot of "Capitol hill." Mr. Rankin was afterwards elected treasurer of state for two terms but left the office in disgrace, a defaulter, and yet, I believe Sam Rankin was as honest a man as ever lived. He was the victim of others. He turned over everything he had, a fine residence in Des Moines and a farm in his home county, made good the deficit and died of a broken heart in Kansas. The amount of his defalcation was $\$ 36,000$, and the funds belonged to the Agricultural college, of which institution he had been treasurer for five years without bond, so well did the trustees regard him. He was the first to make known his defalcation in a letter to the governor. In 1854, James D. Eads, superintendent of Public Instruction, stole $\$ 65,150$ from the school fund, which the state had to make good. These two are the only defalcations of state officers in our history of 70 years. 


\section{Senate Secretary Had Whiskey}

I had another friend in the senate who aided me in securing the clerkship. This was Alvin Saunders, senator from Henry county. He was a brother-in-law to Senator Harlan, through whose influence he later became the first territorial governor of Nebraska and one of its first U.S. senators. He was a thorough business man and a leader in all measures of a business character. The secretary of the senate was George $E$. Spencer, a genuine politician, shrewd, talented, and a little sporty. He kept a bottle of whiskey in his desk, but was a good secretary. After the war, he went south and became a carpet-bag senator from Alabama.

The inauguration of Ralph $\mathrm{P}$. Lowe, the first governor of the state elected as a Republican, ${ }^{5}$ and Oran Faville, the first lieutenant governor (previous to that, there was no such office) was a great event. Leading men from all over the state were there, and it called out the beauty and the fashion and the business men of the new capital city. Every foot of space in representatives hall was occupied. The inaugural address of Governor Lowe was expected to foreshadow important changes in state policy and I was prepared to take notes and make a scoop for my paper. But I was crowcled against the wall and one of the Des Moines' most beautiful girls was crowded against me and I cared nothing more about Governor Lowe and his policies. At night came the inaugural ball in the same room and the maze of flying feet, of charming belles and graceful beaux made it the grandest social event in my life, and convinced me that socially, the new capital was equal to its new honors. The square dance or cotillion was in vogue then, and the entire floor was a mass of rythmic motion. If it were possible to find in Des Moines today, one of the charming girls with whom I danced at that ball, she would be a whitehaired matron and perhaps a great-grandmother.

'James W. Grimes was a Whig when elected governor, but led in organizing the Republican party in Iowa. 
John Edwards was speaker of the house and W. P. Hepburn chief clerk. Senator Kirkwood was the leader of the senate in debate. He was a very plain man, dark sandy hair and beard, rather homely, wore the commonest clothes and his shirt front often shone with tobacco stains, but never with diamonds. His speech was short, terse, explosive, and with few gestures. Early in the session two days were set apart for the discussion of the slavery question, when senators on both sides had occasion to air their political views, their oratory and their argumentative powers. One day, Spencer had occasion to leave the room and asked me to act as secretary for a few minutes. Senator Kirkwood sent up a resolution but I couldn't read it. His chirography was worse than Greeley's, so I handed it to the presiding officer, but he could not read it and sent it back to the senator for him to read. He studied it in silence for a few moments, then gave it up and amidst the laughter of the senate, he stated the substance of it.

Kirkwood became our beloved war governor and for a short term, U.S. senator. When he was a candidate for governor, he met his opponent, A. C. Dodge, in joint discussions. One of these took place in Washington. Dodge was a fine looking man. He had served fifteen years in congress and was four years Minister to Spain. Dressed in finest broadcloth and topped with a fine silk hat, he was the personification of official dignity and superiority. The Democrats brought him into town with the finest carriage and team of black horses they could procure. The Republicans hitched a yoke of oxen to a hayrack and went out to meet Kirkwood. He was driven around the public square, the driver with his gad and calling in stentorian voice "Gee, Haw," while the candidate bowed to the cheering multitudes on the sidewalks. It was in this debate that Kirkwood in his most emphatic way, declared that he would not obey the fugitive slave law. He would suffer the penalty, but would never become a 
slave catcher, noi aid in remanding any human being into slavery. He put the whole force of his eloquence inio the declaration and was loudly cheered. The scene was intensely dramatic and ihrilling. With his conscience for his sanction, he was delying the govermment of the United States.

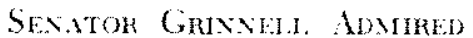

The senator most of my liking was J. B. Grinnell of Poweshiek. He was short and heavy set, with a smiling face and kindly way, the cheery friend of the humblest clerk or doorkeeper. He was a rich man who came from the East to found a college, which he did, thus building for himself a monument that wil! perpetuate his name through all future history of Iowa. He was afterwards elected to congress and died too soon to serve.

Senator Johnson of Otunwa was a very large man with a stentorian voice and he always voted "No." That "No" became a static feature of the senate. During the session, one of our consuls in South America came and delivered a lecture in the representatives hall and introduced an Aztec woman he brought with him. She was dressed in her native costume which was very scanty, and sang a wild weird song with dramatic action. J. N. Dixon was then the most popular editor in Iowa. He was local editur of the State Register, then under the control of the Mills Bros. Dixon's paragraphs were spiced with humor and originality. Will Porter was the legislative reporter for the Democratic paper and was regarded as a sort of free lance, or free booter, and you had to look out or Porter would get you. Wm. Duane Wilson, a genial old Scot. was secretary of agriculture and had an office in the capitol among large quantities of seeds. He was the victim of all the jokers, but was really a useful man. He was fond of his name and kept it prominently in view. He was an uncle to Pres. Woodrow Wilson, I 
am told by Major Fleming, who seems to know everything.

The "Third house" was organized early in the session and its speaker was C. C. Nourse, a handsome and talented young lawyer from Keosauqua. The "Third house" was made up of lobbyists, visiting statesmen, lawyers atlending the supreme court, and ambitious politicians. It was mostly given over to fun, but some of the ablest speeches of the winter were made in the "Third house." It was an open forum to all who had ability and courage to express their views and could do it with wit and eloquence.

\section{Assermay Had Exceptional Leabers}

Let me recount a few of the leading men of the Seventh General Assembly. They were Kirkwood, Saunders, Laughridge, Grinnell, Trimble, Belknap, Wilson and McCrary. Kirkwood was twice governor and also senator. Alvin Saunders was first territorial governor of Nebraska and one of its first U.S. senators. J. B. Grinnell and Wm. Laughridge were elected members of congress. James F. Wilson of Fairfield also became a member of congress and senator. W. W. Belknap was appointed secretary of war, George W. McCrary, secretary of war and federal judge. If I include James W. Grimes and W. P. Hepburn, who were officially a part of this general assembly, I will have a group of men rarely equaled in any subsequent legislature. They are the men most referred to in our history.

James Harlan, probably the ablest and grandest man the state has yet produced, was intimately connected with this period. He was the first Republican elected to congress from Iowa. He was chosen U.S. senator while he was president of the Wesleyan university at Mt. Pleasant. I heard him preach the funeral sermon of a young lady student which was nearly two hours long, and so beautiful and touching that the immense audience thought it too short. And yet, personally he was rather cold and distant, so that young people 
rarely got in close touch with him. His wife was a pretty, gay, social butterfly. It was said that the senator chose her to keep the social balance equal. They had one child, a daughter, who became the wife of Robert Lincoln, son of the president. You see, I am somewhat gossipy, but then personality is the charm of history.

James F. Wilson was one of the brainiest men of Iowa. He was in congress during the war period and was the "Plumed Knight" of the house, as Blaine was of the senate, hurling his shining lance at the secession leaders. As a debater, he had no equal there and then. As a member of the house in the Seventh General Assembly he was rather quiet, but when he spoke, it was as a master and often he was called on to straighten out a parliamentary tangle into which the younger members frequently involved the proceedings.

Of W. W. Belknap of Keokuk, I can recall but little, save that he was a large fine-looking man, with classic clean-shaven face. George W. McCrary was the youngest member, being only 22 .

\section{Session Marked Changes}

Another reason for giving pre-eminence to the Seventh General Assembly is that it was the turning point in the history of the state - financially, industrially and politically. It created a wise banking law and the State Bank of Iowa and its branches gave the people a much needed safe and reliable currency. It reorganized and improved the educational system, and established the Iowa State Agricultural college, which is doing so much for the state today. In short, the state was then leaving its youthful condition and entering upon its manhood.

Politically, the change was even more marked. Prior to that date, the territory and state had been in the control of the Democrat party and that party was pro-slavery. Our representatives in congress, Dodge and Jones, had voted against the Wilmot proviso and 
in favor of the fugitive slave law. That fact, in the light of Iowa sentiment today, cast a shade on the good name of the state. The slavery question dominated every other issue as it was the only national issue. No bill, however, insignificant in its object, could pass congress without first considering its bearing upon slavery.

The slavery question came near dividing Iowa into two states. Congress fixed the boundaries of the new state by drawing a straight line from the northeast corner of Kossuth county on the north, to the southwest corner of Ringgold county on the south, and adding eleven counties from southeast Minnesota. The people of Iowa would not have it so and twice voted down the proposed constitution with the boundaries thus fixed by congress, and would have remained out of the union several years more, rather than split the state in that way. The object of those dividing the state was this: the South was straining every nerve to increase its power in the national government in order to overcome the growing free-soil sentiment in the North.

A proposition was brought forward to cut Florida in two, thus giving the South more senators and additional representatives. This was offset by the proposed division of Iowa. General Dodge at first opposed it with great vigor, but afterwards favored it, thinking perhaps that the sooner the state was admitted, the sooner he would become one of its senators. Happily there was no necessity for fighting slavery by sacrificing Iowa. "We are indebted for its defeat," says Governor Gue, "to three young Democrats: Enoch W. Eastman, Theo. S. Parvin and Frederick D. Mills, who stumped the state and secured a majority of 995 against division. It was a critical period in Iowa history and the people of the state will never cease to honor the three young men who by their courage and wisdom preserved for all time, its symmetrical pro- 
portions." Iowa is just as we want it if we had the choice of fixing its boundary today.

\section{The Assembly Personnel}

The senate of 1858 was composed of 33 members, compared with 50 in the senate of the present assembly. They were John R. Allen of Lee, Samuel Anderson of Monroe, Gideon S. Bailey of Van Buren, David T. Brigham of Lee, Aaron Brown of Fayette, Henry B. Carter of Clayton, John M. Cathcart of Marion, Lyman Cook of Burlington, George M. Davis of Clinton, W. T. Davis of Polk, Charles Foster of Washington, J. B. Grinnell of Poweshiek, Jeremiah Jenkins of Jackson, John A. Johnson of Wapello, S. J. Kirkwood of Johnson, Wm. Laughridge of Mahaska, George McCoy, M. L. McPherson of Madison, Joseph Mann of Jones, Marius E. Neal of Marion, A. C. Patterson of Muscatine, W. H. Pusey of Council Bluffs, John W. Rankin of Lee, Wm. M. Reed of Jefferson, Samuel Reiner of Louisa, Wm. G. Thompson of Linn, Nicholas J. Rusch of Scott, O. P. Sheraden of Keokuk, Alvin Saunders of Henry, Wm. G. Stewart of Dubuque, John W. Warner of Decatur. Senator Wm. G. Thompson died a few years ago, the last survivor of the senate of 1858.

Senator Rusch was a genial German who made himself popular by his good nature, and the next year was elected lieutenant governor, and beer and wine were exempted from the prohibitory law to placate him and the beer drinking. Germans. That was considered good politics. Senator Bailey, a dignified gentleman from Van Buren and an earnest Democrat, read an original poem hitting the peculiarities of many of the senators in a humorous manner. Senator Jairus Neal was a prominent lawyer, but prided himself on his clothes which were of blue jeans, made in his own home and from the wool of his own sheep. I can never forget Jonathan W. Cattell, the Quaker senator from Linn county. In the house was Dennis Mahoney, 
editor of the Dubuque Herald, who when the war came, was arrested and confined in a Federal prison because of disloyal editorials. He was the only disloyal Irishman I ever heard of. C. C. Carpenter and B. F. Gue were members of the house, who later exercised a lasting influence on the state, the one as governor and the other as lieutenant governor and historian.

The officers of the senate were secretary at $\$ 5$ per day; assistant secretary, $\$ 3$; enrolling clerk, $\$ 3$; engrossing clerk, $\$ 3$; sergeant at arms, $\$ 3$; door-keeper, $\$ 3$; first messenger, $\$ 2.50$; second messenger, $\$ 2$; and two firemen at $\$ 2$ each. All were elected by a strict party vote -22 Republicans to 11 Democrats. Not a woman in any position in the legislature then, quite in contrast with today, when both houses are full of them and legislation could hardly proceed without the bright-minded and nimble-fingered typewriter girls. J. P. Patrick, one of the messengers of that winter, is still living in Des Moines, and besides myself is the only living representative of the Seventh General Assembly.

The last night of the session was given over to fun and frolic, the hands of the clock being turned back to prevent the departure of the day. In the morning, the floor was snowed deep in paper wads. No doubt, every subsequent legislature has followed this precedent, the members throwing off their dignity and resorting to boyish pranks. Time has obliterated from my memory many things of interest in that faraway legislature, but it can never efface my impression that it was great - great in its men and in its achievements. 
Copyright of Annals of Iowa is the property of State of Iowa, by \& through the State Historical Society of Iowa and its content may not be copied or emailed to multiple sites or posted to a listserv without the copyright holder's express written permission. However, users may print, download, or email articles for individual use. 